DOI: 10.21802/artm.2019.3.11.105.

УДК 616-006.6

\title{
КОРОТКО ПРО СКРИНІНГ КОЛОРЕКТАЛЬНОГО РАКУ
}

\author{
Н.I. Мельничук ${ }^{1}$, Г.І. Шабат ${ }^{1}$, І.К. Чурпій ${ }^{2}$ \\ ${ }^{\text {I} С е к ц і я ~ к о л о р е к т а л ь н о і ̈ ~ х і р у р г і і ̈, ~ в і д д і л е н н я ~ х і р у р г і і ̈, ~ Б р и г х а м ~ і ~ ж і н о ч а ~ л і к а р н я, ~}$ \\ Гарвардський медичний університет, вул. Св. Франиіса 75, Бостон, Массачусетс, США, \\ ORCID ID: 0000-0001-5774-050X, ORCID ID: 0000-0002-7223-9526, \\ e-mail:galyna.shabat@gmail.com \\ ${ }^{2}$ Івано-Франківський національний медичний університет, кафедра хірургії, \\ м. Івано-Франківськ, Украӥна, \\ ORCID ID: 0000-0003-1735-9418
}

Резюме. На сьогоднішній день, колоректальний рак залишається одним з найбільш важливих проблем клінічної онкології, тому що є другим за летальністю в структурі онкологічних захворювань в світі (1 з 3 осіб, в яких діагностовано колоректальний рак помирають від цього захворювання). В Україні колоректальний рак посідає четверте місце серед причин смертності від онкологічної патології в чоловіків, та на третьому - у жінок.

В статті коротко розглянуто фактори ризику, скринінгові методи колоректального раку, економічну ефективність та шляхи впровадження скринінгової програми. Завдяки скринінгу колоректального раку можна виявляти доброякісні новоутворення та діагностувати рак на ранній стадії, що дозволяє проводити своєчасне та високоякісне лікування, а також знижувати смертність від даного захворювання.

Оскільки Україна належить до країн із низьким та середнім рівнем доходу, то впровадження ефективної скринінгової програми для КРР зустрічає ряд перешкод. В більшості високорозвинених країн світу скринінг КРР розпочинається у віці 45 - 50 років, але в осіб з підвищеним ризиком скринінг розпочинається раніше.

Всі скринінгові програми крім покращення якості та збільшення тривалості життя пацієнтів $\epsilon$ ще і економічно ефективними, порівнюючи із ситуацією відсутності скринінгу.

Скринінг найкраще впроваджувати шляхом розробки системи ідентифікації прицільної когорти пацієнтів, які підлягають скринінгу з урахуванням факторів ризику, проводити регулярне оновлення інформації тих пацієнтів, в яких виявлено позитивні результати обстеження в в процесі подальшого лікування та спостереження.

В статті надано аналіз ефективності трьох скринінгових методик колоректального раку для пацієнтів із помірним ризиком розвитку раку у віці від 50 до 75 років.

Ключові слова: колоректальний рак, скринінг, економічна ефективність.

Вступ. На сьогоднішній день, колоректальний рак (КРР) залишається одним з найважливіших в клінічній онкології, тому що є другим за летальністю серед онкологічної патології в Світі (1 з 3 осіб в кого діагностовано КРР помирають від цього захворювання) [1]. В Україні КРР знаходиться на четвертому місці серед причин смертності від онкологічної патології в чоловіків та на третьому - у жінок [2]. Найчастіше КРР виникає в осіб віком після 50 років. Завдяки функціонуванню ефективної скринінгової програми, що дозволяє своєчасно видаляти премалігнізовані аденоми, запобігаючи виникненню КРР та проводити хірургічне лікування вже наявного локального раку на початковій стадії, можна запобігти смерті від КРР [3]. Скринінг дозволяс знизити на 53 \% смертність від КРР [3]. У високорозвинених країнах Світу для скринінгу КРР найчастіше використовується колоноскопія близько $61 \%$ [4].

Впровадження ефективної скринінгової програми для КРР зустрічає ряд перешкод, оскільки Україн входить в групу країн із низьким та середнім рівнем доходу [5]. Не $\epsilon$ новиною той факт, що багато пацієнтів в Україні звертаються за медичною допомо- гою тільки після появи клінічної симптоматики, що приводить до запізнілої діагностики, несвоєчасного лікування та високої смертності від КРР. Проблема занедбаних форм раку та високої смертності від онкологічної патології тривалий час обговорюється на Всеукраїнських конгресах та форумах, але поки що радикальних значних змін в позитивному напрямку на загальнодержавному рівні не дуже помітно.

Пошук найбільш цільової когорти осіб для скринінгу КРР. В більшості високорозвинених країн Світу скринінг КРР розпочинається у віці $45-50$ років, але в осіб $з$ підвищеним ризиком скринінг розпочинається раніше. Для розуміння, хто входить в групу з підвищеним ризиком, потрібно проаналізувати фактори ризику. Для КРР факторами ризику є:

- Генетичні фактори ризику. Необхідно ретельно збирати сімейний анамнез, тому що близько $10 \%$ дорослих відзначають історію КРР в сім'ї $[6,7]$; із них близько $20 \%$ хворіє КРР $[8,9]$. Бажано, щоб всі пацієнти, в кого діагностовано КРР пройшли імуногістохімічний аналіз на наявність синдрому Лінча, a ті, в кого аналіз виявився позитивним повинні повідомити родичів, які, в свою чергу повинні отримати 
генетичну консультацію та діагностику з відповідним скринінгом [10].

Демографічні фактори ризику, а саме: вік - захворюваність КРР зазвичай підвищуються 3 віком; paca - в США серед чорних пацієнтів захворюваність та смертність від КРР вища, ніж в інших етнічних групах [11]; стать - порівнюючи дані скринінгової колоноскопії у чоловіків та жінок, у чоловіків переважає аденоматоз, множинні аденоматозні поліпи в молодшому віці (8,0 порівняно до 4,3\%) та КРР (1,4 до $0,6 \%)[12,13-15]$.

- Специффічні клінічні фактори ризику: Хронічні запальні захворювання кишечника можуть приводити до підвищеного ризику виникнення КРР, особливо при поширеному ураженні (панколіт) та довготривалому захворюванні (рак розвивається 3 місця дисплазії частіше, ніж 3 поліпа). Перенесений КРР в анамнезі підвищує ризик виникнення метахронного раку. Історія аденоматозних колоректальних поліпів збільшує ризик виникнення КРР, особливо у випадку множинних поліпів, великих розмірів чи з ворсинчастою структурою [16]. Гамартомні поліпи характеризуються незначним потенціалом малігнізації, але в пацієнтів 3 наявністю даних поліпів може бути дещо підвищений ризик КРР. Променева терапія захворювань органів? черевної порожнини в дитячому віці приводить до підвищеного ризику гастроінтестінальних новоутворень в дорослому віці, особливо КРР. Променева терапія при раку простати асоціюється 3 підвищеним ризиком раку прямої кишки [17]. Ендометріальний рак в молодому віці (50 років і молодші) може підвищувати ризик КРР [18]. ВІЛ-інфіковані пацієнти чоловічої статі у віці понад 50 років можуть страждати від більшої наявності новоутворень кишечника та мати більшу схильність до розвитку анальних новоутворень [19].

До додаткових факторів ризику належать: акромегалія, пересадка нирок, цукровий діабет, андрогенний дисбаланс, зловживання алкоголем, ожиріння, куріння, та фактори харчування [20, 22].

Короткий опис скринінгових методик КРР. На сьогоднішній день рекомендовані методи скринігу КРР поділяються на дві основні категорії, до них належать методи, що базуються на дослідженні калу та візуалізації кишечника (ендоскопічні методи). Методи візуалізації (ендоскопічні методи) дозволяють не тільки діагностувати, але і запобігти виникненню раку шляхом видалення аденоматозних поліпів до початку їхньої малігнізації.

\section{- Методи на основі дослідження калу:}

- Аналіз калу на приховану кров (gFOBТ): Якщо було обрано даний метод, повинні бути зібрані самим пацієнтом вдома три послідовні зразки калу. Проведений в лікарні чи кабінеті лікаря gFOBТ не є чутливим для скринінгу КРР. Зразки калу отримані лікарем під час ректального обстеження не підходять для скринінгу. Даний аналіз gFOBТ може дати багато хибно-позитивних результатів. Аналіз $є$ неінвазивним, але у випадку негативного результату його потрібно повторювати щорічно. Якщо gFОВТ позитивний, потрібно проводити колоноскопію. gFОВТ повинен проводитися з використанням чутливої гваякової проби (наприклад, Hemoccult SENSA) без регідра- тації. Для правильного проведення gFОВТ, згідно рекомендацій виробника, необхідно утриматися від вживання нестероїдних протизапальних препаратів, включно з аспірином (не більше 1 таб/день) протягом 7 днів; виключити високі дози (1000 чи більше мг/д) вітаміну C та червоного м'яса протягом 3 днів. Аналіз може зазнати ушкоджень під дією високої температури навколишнього середовища [23].

- Імунохімічний аналіз калу (FIT): Дослідження показують, що FIT порівняно 3 gFОВТ, краще підходить для скринінгу з більшою чутливістю без втрати специфічності та 3 кращим показником виявлення обширних аденом [24-26]. Імунохімічні аналізи калу зазвичай виконуються на одному зразку калу, який пацієнт збирає вдома; при можливості проводити кількісний аналіз, якісний аналіз проводиться тільки при неможливості провести кількісний аналіз. Для проведення FIT не потрібно дотримуватися дієти чи обмежувати вживання медикаментів. Після позитивного аналізу потрібно проводити колоноскопію. Необхідно пояснити пацієнту про необхідність доставки аналізу після його отримання негайно, особливо при високій температурі навколишнього середовища [27], тому що гемоглобін в зразку може розпадатися, знижуючи чутливість аналізу [25].

- ДНК - імунохімічний аналіз калу (FIT-DNA) - багатоцільовий ДНК аналіз калу (MT-sDNA), що поєднує в собі аналізи ДНК калу, імунохімічний (FIT), і ДНК метилювання, у вигляді аналізу Cologuard. Для проведення аналізу достатньо надіслати в лабораторію зразок з одного випорожнення.

\section{- Ендоскопічні та радіологічні обстеження}

- Колоноскопія характеризується високою чутливістю та специфічністю. Перевагами методики є можливість одномоментного видалення утворення під час обстеження. Деякі пацієнти не погоджуються на дану методику через недостатньо правильну поінформованість, або через те, що зазвичай для проведення процедури необхідна седація та підготовка кишечника, яка в свою чергу може бути причиною дегідратації та електролітного дисбалансу, а також під час проведення обстеження $є$ ризик перфорації кишечника чи кровотечі.

- "Віртуальна колоноскопія" - КT (комп'ютерна томографія) колонографія - володіє чутливістю приблизно такою, як і колоноскопія; потребує підготовки кишечника; не вимагає седації та не несе в собі ризику перфорації кишечника; при виявленні утворень чи будь-яких патологічних відхилень необхідно проводити колоноскопію. Незначні дози радіаційного опромінення під час частого скринігу цією методикою можуть підвищувати ризик виникнення раку.

- Сигмоскопія може проводитися у пацієнтів 3 мінімальною підготовкою кишечника, але тільки на відстані 60 см від анального отвору, не вимагає седації. Виявлені відхилення від норми в дистальному відділі кишечника зазвичай потребують проведення тотальної колоноскопії для дообстеження всього товстого кишечника. Добрих результатів скринінгу досягається при поєднанні 3 проведенням імунохімічного (FIT) або аналізу на приховану кров (gFOBT) щороку. Так як більше половини випадків КРР локалізуються в ділянці сігми і прямої кишки. 
- Капсульна колоноскопія базується на тому, що пацієнт проковтує капсулу з маленьким відеореєстратором, що дозволяє оглядати кишечник під час проходження капсули по ньому. Проведення процедури не вимагає седації чи підготовки кишечника. Недоліки: капсульна ендоскопія не дозволяє проводити біопсію чи видалення поліпів, тому при виявленні патологічних відхилень необхідно проводити колоноскопію для діагностичної біопсії або лікування.

\section{- Аналізи, які не рекомендуються для проведення скринінгу КРP}

- Аналіз калу на приховану кров gFОВТ виконаний в кабінеті лікаря чи в амбулаторії. Одиничний виконаний в амбулаторних умовах gFОВТ з послідуючим ректальним обстеженням не застосовується для адекватного скринінгу через низьку чутливість до аденом чи КРР [23].

- Ірігоскопія/графія 3 подвійним контрастуванням більше не рекомендується для скринінгу КРР через недостатню чутливість чи специфічність порівняно 3 іншими скринінговими методами [22].

Погляд на економічну ефективність скринінгу КРР. Як висвітлено на основі розробленої когортної моделі Маркова в статті N. Melnitchouk et al, що скринінг колоректального раку в Україні може бути економічно ефективним [4] можливо [5 ]. В статті приведено аналіз ефективності трьох скринінгових методик колоректального раку (1 - аналіз калу на приховану кров щороку із послідуючою колоноскопією при наявності позитивного результату; 2 сигмоїдоскопія та аналіз калу на приховану кров кожних 5 років із послідуючою колоноскопією при наявності позитивного результату; 3 - колоноскопія кожних 10 років) для пацієнтів із помірним ризиком розвитку раку у віці від 50 до 75 років. Безпосередні витрати на проведення вищеперелічених скринінгових методик порівнювалися 3 безпосередніми (прямими) витратами на лікування пацієнтів при відсутності скринінгу (тобто як у ситуації сьогодення в Україні).

Дослідження проведені авторами показали, що всі скринінгові методики були дешевшими та ефективнішими в порівнянні $з$ коштами, які витрачаються на лікування пацієнтів при відсутності скринінгу, найефективнішою серед них виявилася колоноскопія кожних 10 років, яка знижувала показники смертності на 73\%. Аналіз калу на приховану кров знижував показники смертності на 61,6\%, а сигмоскопія та аналіз калу на приховану кров знижували смертність на 64\%. Крім зниження смертності, що $\epsilon$ найважливішим, усі скринінгові методики виявилися ще і економічно ефективними, особливо колоноскопія, що дозволяе заощаджувати значні кошти виявляючи передракові стани та КРР на ранніх стадіях із проведенням своєчасного та високоякісного лікування.

Шляхи впровадження скринінгової програми. Для ефективного впровадження скринінгової програми необхідно [28, 29]:

- створити систему для визначення серед населення груп ризику (жителі певних географічних районів), провести оцінку даних індивідуальних факторів ризику, включаючи вік, стать, сімейний анамнез, результати попереднього скринінгу. Електронні медичні записи можуть полегшити створення національного реєстру для цільового скринінгу.

- визначити індивідуальну відповідну скринінгову стратегію (рутинний скринінг для пацієнтів помірного ризику, високого ризику та генетичних консультацій).

- створити інтерактивну систему для постійного оновлення скринінгової інформації 3 розрахунком ризику захворювання.

- розпочинати скриніг у відповідному віці для виявлення пацієнтів 3 раком чи передраковими захворюваннями.

- проводити скринінг у відповідні проміжки часу для тих осіб в кого не діагностовано патології на попередніх обстеженнях.

- дообстежувати пацієнтів 3 діагностованими поліпами або раком, з метою біопсії чи ендоскопічного видалення при необхідності.

- проводити лікарське спостереження за особами 3 високим ризиком (зазвичай ті, в кого знайдено великі ( $\geq 8$ мм) аденоматозні поліпи) для виключення нових утворень.

- доступ до лікування та спостереження пацієнтів 3 діагностованим раком.

\section{Висновки:}

Завдяки скринінгу КРР можна виявляти премалігнізовані утворення та виявляти рак на ранній стадії, що дозволяє проводити своєчасне та високоякісне лікування, а також сприяє зниження смертності від КРР.

Всі скринінгові програми крім покращення якості та збільшення тривалості життя пацієнтів є ще i економічно ефективними порівнюючи із ситуацією відсутності скринінгу.

Скринінг найкраще впроваджувати шляхом розробки системи ідентифікації прицільної когорти пацієнтів які підлягають скринінгу (включаючи фактори ризику), проводити регулярне оновлення інформації, та навігацію тих пацієнтів в кого виявлено позитивні результати скринінгу в послідуючому процесі лікування та спостереження.

\section{References:}

1. SEER Stat Fact Sheet; colon and rectum. National Cancer Institute http://seer.cancer. gov/statfacts/html/ colorect.html (Accessed on June 28, 2016).

2. Bulletin of the National Cancer Registry No. 17 "Cancer in Ukraine, 2014-2015".

3. World Health Organization; International Agency for Research on Cancer http://gco.iarc.fr/today/fact-sheetscancers? cancer $=6 \&$ type $=0 \&$ sex $=0$ (Accessed on November 22, 2016).

4. Edwards BK, Ward E, Kohler BA, et al. Annual report to the nation on the status of cancer, 1975-2006, featuring colorectal cancer trends and impact of interventions (risk factors, screening, and treatment) to reduce future rates. Cancer 2010; 116:544.

5. Nelya Melnitchouk. Cost-effectiveness of colorectal cancer screening in Ukraine / Nelya Melnitchouk, Djøra 
I. Soeteman, Jennifer S. Davids, Adam Fields, Joshua Cohen, Farzad Noubary, Andrey Lukashenko, Olena O. Kolesnik, Karen M. Freund//Cost Effectiveness and Resource Allocation, 2018, Volume 16, Number 1, Page 1 9. Telford JJ, et al. The cost-effectiveness of screening for colorectal cancer. CMAJ. 2010; 182(12):1307-13.

6. Petersen GM. Genetic epidemiology of colorectal cancer. Eur J Cancer 1995; 31A:1047.

7. Fuchs CS, Giovannucci EL, Colditz GA, et al. A prospective study of family history and the risk of colorectal cancer. N Engl J Med 1994; 331:1669.

8. Lin JS, Piper M, Perdue LA et al. Screening for colorectal cancer: A systematic review for the US Preventive Services Task Force: Evidence synthesis no. 135. AHRQ publication 14-05203-EF-1, Agency for Healthcare Research and Quality, Rockville, MD, 2016.

9. Burt RW, Bishop DT, Lynch HT, et al. Risk and surveillance of individuals with heritable factors for colorectal cancer. WHO Collaborating Centre for the Prevention of Colorectal Cancer. Bull World Health Organ 1990; 68:655.

10. Gulland A. All patients with colorectal cancer should be tested for genetic condition, NICE advises. BMJ 2017; 356:j998.

11. Jemal A, Siegel R, Xu J, Ward E. Cancer statistics, 2010. CA Cancer J Clin 2010; 60:277.

12. Ferlitsch M, Reinhart K, Pramhas S, et al. Sexspecific prevalence of adenomas, advanced adenomas, and colorectal cancer in individuals undergoing screening colonoscopy. JAMA 2011; 306:1352.

13. Regula J, Rupinski M, Kraszewska E, et al. Colonoscopy in colorectal-cancer screening for detection of advanced neoplasia. N Engl J Med 2006; 355:1863.

14. Rundle AG, Lebwohl B, Vogel R, et al. Colonoscopic screening in average-risk individuals ages 40 to 49 vs 50 to 59 years. Gastroenterology 2008; 134:1311.

15. Brenner H, Hoffmeister M, Stegmaier C, et al. Risk of progression of advanced adenomas to colorectal cancer by age and sex: estimates based on 840,149 screening colonoscopies. Gut 2007; 56:1585.

16. Atkin WS, Morson BC, Cuzick J. Long-term risk of colorectal cancer after excision of rectosigmoid adenomas. N Engl J Med 1992; 326:658.

17. Baxter NN, Tepper JE, Durham SB, et al. Increased risk of rectal cancer after prostate radiation: a populationbased study. Gastroenterology 2005; 128:819.

18. Singh H, Nugent Z, Demers A, et al. Risk of colorectal cancer after diagnosis of endometrial cancer: a population-based study. J Clin Oncol 2013; 31:2010.

19. Bini EJ, Park J, Francois F. Use of flexible sigmoidoscopy to screen for colorectal cancer in HIVinfected patients 50 years of age and older. Arch Intern Med 2006; 166:1626.

20. Tomeo CA, Colditz GA, Willett WC, et al. Harvard Report on Cancer Prevention. Volume 3: prevention of colon cancer in the United States. Cancer Causes Control 1999; 10:167.

21. Chan AT, Giovannucci EL. Primary prevention of colorectal cancer. Gastroenterology 2010; 138:2029.

22. Winawer S, Fletcher R, Rex D, et al. Colorectal cancer screening and surveillance: clinical guidelines and rationale-Update based on new evidence. Gastroenterology $2003 ; 124: 544$.
23. Collins JF, Lieberman DA, Durbin TE, et al. Accuracy of screening for fecal occult blood on a single stool sample obtained by digital rectal examination: a comparison with recommended sampling practice. Ann Intern Med 2005; 142:81.

24. Guittet L, Bouvier V, Mariotte N, et al. Comparison of a guaiac based and an immunochemical faecal occult blood test in screening for colorectal cancer in a general average risk population. Gut 2007; 56:210.

25. Robertson DJ, Lee JK, Boland CR, et al. Recommendations on fecal immunochemical testing to screen for colorectal neoplasia: a consensus statement by the US Multi-Society Task Force on colorectal cancer. Gastrointest Endosc 2017; 85:2.

26. Weinberg DS, Barkun A, Turner BJ. Colorectal Cancer Screening in the United States: What Is the Best FIT? Ann Intern Med 2017; 166:297.

27. Doubeni CA, Jensen CD, Fedewa SA, et al. Fecal Immunochemical Test (FIT) for Colon Cancer Screening: Variable Performance with Ambient Temperature. J Am Board Fam Med 2016; 29:672.

28. Doubeni CA. Precision Screening for Colorectal Cancer: Promise and Challenges. Ann Intern Med 2015; 163:390.

29. Andermann A, Blancquaert I, Beauchamp S, Déry V. Revisiting Wilson and Jungner in the genomic age: a review of screening criteria over the past 40 years. Bull World Health Organ 2008; 86:317.

\section{УДК 616-006.6 \\ КРАТКО О СКРИНИНГЕ КОЛОРЕКТАЛЬНОГО РАКА}

\section{Н.И. Мельничук ${ }^{1}$ Г.И. Шабат ${ }^{1}$, И.К. Чурпий ${ }^{2}$}

${ }^{I}$ Секичия колоректальной хирургии, отделение хирургии, Бригхам и Женская больнициа, Гарвардской медиичинский университет, ул. Св. Франичиса 75, Бостон, Массачусетс, США,

ORCID ID: 0000-0001-5774-050X,

ORCID ID: 0000-0002-7223-9526,

e-mail: galyna.shabat@gmail.com

${ }^{2}$ Ивано-Франковский нацииональний медицинский университет, кафедра хирургии, г. Ивано-Франковск, Украина,

ORCID ID: 0000-0003-1735-9418

Резюме. На сегодняшний день, колоректальный рак остается одним из важнейших в клинической онкологии, так как является вторым по летальности среди онкологической патологии в мире (1 из 3 человек, у которых диагностирован колоректальный рак, умирает от этого заболевания). В Украине колоректальный рак находится на четвертом месте среди причин смертности от онкологической патологии у мужчин, и на третьем у женщин.

В статье кратко рассмотрены факторы риска, скрининговые методы колоректального рака, экономическая эффективность и пути внедрения скрининговой программы. Благодаря скринингу колоректального рака можно выявлять премалигнизовани образования и выявлять рак на ранней стадии, он позволяет 
проводить своевременное и качественное лечение, а также снижать смертность от данного заболевания.

Поскольку Украина входит в группу стран с низким и средним уровнем дохода, то внедрение эффективной скрининговой программы для КРР встречает ряд препятствий. В большинстве высокоразвитых стран мира скрининг КРР начинается в возрасте 45 - 50 лет, но у лиц с повышенным риском скрининг начинается раньше.

Все скрининговые программы, кроме улучшения качества и увеличения продолжительности жизни пациентов, еще и экономически эффективные, сравнивая с ситуацией отсутствия скрининга.

Скрининг лучше внедрять путем разработки системы идентификации прицельной когорты пациентов, которым нужен скрининг (включая факторы риска), проводить регулярное обновление информации и навигацию тех пациентов, у которых выявлены положительные результаты обследования в последующем процессе лечения и наблюдения.

В статье дан анализ эффективности трех скрининговых методик колоректального рака у пациентов с умеренным риском развития рака в возрасте от 50 до 75 лет.

Ключевые слова: колоректальный рак, скрининг, экономическая эффективность.

\section{UDC 616-006.6 \\ SHORT REVIEW OF COLORECTAL CANCER SCREENING}

\author{
N.I. Melnitchouk ${ }^{1}$, G.I. Shabat ${ }^{1}$, I.K. Churpiy ${ }^{2}$ \\ ${ }^{1}$ Section of Colorectal Surgery, Department of Surgery, \\ Brigham and Womans Hospital, Harvard Medical \\ School, 75 St Francis str., Boston, MA, USA, \\ ORCID ID: 0000-0001-5774-050X, \\ ORCID ID: 0000-0002-7223-9526, \\ e-mail: galyna.shabat@gmail.com \\ ${ }^{2}$ Ivano-Frankivsk National Medical University, \\ Department of Surgery, Ivano-Frankivsk, Ukrainian, \\ ORCID ID: 0000-0003-1735-9418
}

Abstract. Until nowadays colorectal cancer (CRC) remind one from the most important in the field of clinical oncology, because there is on the second position among the most important killers in oncologic pathology all around the World (one from three persons with diagnosed colorectal cancer died from diseases). In Ukraine colorectal cancer is located on the forth place among the death caused by oncologic pathology in man and on the third place - in women. Most commonly colorectal cancer diagnosed among the persons more than 50 years old. Thanks to the work of very effective screening program is possible to identify premalignant adenomas in time and by this way block development of colorectal cancer is possible to remove colorectal cancer on the early stage of diseases and avoid the colorectal cancer related death. Screening permit to decries on the $53 \%$ colorectal cancer mortality. In high-developed Countries of the World for colorectal cancer, screening is predominantly used colonoscopy (around $61 \%$ ).

Such as Ukraine is the low to middle income Country, the effective screening program for colorectal cancer has some barriers on the way to improvement. There is not nothing new to say, that many patients in Ukraine ask for medical care only after clinical symptoms development, what cause late diagnosis and treatment, and of course high colorectal cancer mortality rate. The problem of neglected disseminated cancer and high mortality rate caused by oncologic pathology a lot of time is discussed on All-Ukrainian Congresses and Forums, but until now, there is not visible radical important changes in the positive way on the general level of State. In the article shortly described risk factors, screening methods of colorectal cancer, economical effectiveness of screening, and ways of improvement of screening program.

Screening is best implemented by developing a system for identifying a target cohort of patients who require screening (including risk factors), regularly updating information, and navigating those patients who have found positive screening results.

Risk groups include people, divided into specific categories, such as age, gender, family history, prescreening results.

There are several rules for screening efficiency:

- initiate screening at the appropriate age to identify patients with cancer or precancerous lesions.

- screening at appropriate intervals for those who have not found pathology in previous examinations.

- examine patients with diagnosed polyps or cancer with a view to biopsy or endoscopic removal as needed.

- to conduct medical surveillance of high-risk individuals (usually those with large $(\geq 8 \mathrm{~mm})$ adenomatous polyps) to exclude new entities.

- access to treatment and monitoring of patients with diagnosed cancer.

Nowadays, the recommended methods of CRC screening are divided into two main categories, including methods based on stool examination and bowel imaging (endoscopic methods). Endoscopic methods not only diagnose but also prevent cancer by removing adenomatous polyps before their malignancy begins. Also, we tried to explain and prove the expediency of the screening methods, because the current situation in Ukraine shows that the money spent on the treatment of late diagnosed CRC can be reduced and thus not only save money but also increase the level of health of the nation.

Keywords: colorectal cancer, screening, economical effectiveness.

Стаття надійшла в редакцію 10.09. 2019 р. 